\title{
THE HeLPLESS PROTECTING THE VULNERABLE? DEFENDING COERCED MOTHERS CHARGED WITH FAILURE TO PROTECT
}

\section{Brenda Midson*}

In a number of jurisdictions failure to protect a child from violence renders a person liable if a duty is owed to the child. This duty presumes the defendant has the capacity to act positively to protect the victim, which has implications for defendants who are also subjected to violence or coercion. In the understandable haste to prosecute and prevent child abuse, there is a risk of neglecting the realities of other vulnerable people. Consequently the criminal justice system ought to reject a binary approach to victims and offenders, recognising that defendants may also be victims and that mothers, due to the coercive control exerted by intimate partners, may also be vulnerable.

In New Zealand there are no statutory or common law defences that operate to exculpate a mother charged with failing to protect her child from the violence of another. This article argues for the creation of an affirmative defence that takes into account the totality of a coerced mother's circumstances in considering whether she has, in fact, failed her child.

\section{INTRODUCTION}

In many jurisdictions, failure to protect one's child from violence makes a parent criminally liable if the omission is voluntary. In South Australia and England and Wales, this duty is extended to others, such as people who have assumed responsibility for the child or members of the child's household. In New Zealand the duty also applies to members of a victim's household by virtue of $\mathrm{s}$ 195A of the Crimes Act 1961.

As stated in s 195A victim means a child or a "vulnerable adult". This latter term is defined as "a person unable, by reason of detention, age, sickness, mental impairment, or any other cause, to

* Senior Lecturer, Te Piringa Faculty of Law, University of Waikato, New Zealand. I would like to thank Professor Andrew Ashworth for his helpful comments on earlier drafts of this article. 
withdraw himself or herself from the care or charge of another person". ${ }^{1}$ While this definition does not exclude temporary circumstances making the person vulnerable, it must also be proved that she was under the care or charge of another, and unable to withdraw herself from such care. The section, therefore, is unlikely to apply to a victim of domestic violence who fails to protect her child, notwithstanding that she may also be vulnerable. Due to the psychological consequences of an abusive relationship, a person who has care of a child may not always be in a position to protect the child. This applies both to mothers who are bound by the common law duty, as well as other household members who are bound by the statute.

In New Zealand there are no statutory defences or common law defences that operate to exculpate a mother charged with failing to protect her child from the violence of another. This article argues for the creation of an affirmative defence that recognises the realities of coerced mothers and operates to take into account the totality of a woman's circumstances, available resources and the history of her partner's abusive behaviour, in considering whether she has, in fact, failed her child.

This article will begin with an examination of the duty to protect before considering theories relating to the psychological effects of domestic violence and coercion and how these phenomena impact on the ability of mothers to protect their children in a gender-biased system. The article will conclude with an analysis of the current legal position in New Zealand vis-à-vis defences for women charged with failure to protect, and due to the unsuitability of this position, a proposal for a new affirmative defence will be detailed.

\section{BACKGROUND AND THEORETICAL UNDERPINNINGS}

\section{A The Duty to Protect}

There are a number of ways in which a mother can fail her child, but for most legal purposes, failures occur where there is knowledge of a risk of abuse to the child coupled with a failure to notify authorities, remove the child from the risk, or to seek other forms of help for the child such as medical treatment.

The law has long distinguished between acts and omissions. In general terms liability only arises when the accused is under some legal duty to act and fails to do so. The distinction between acts and omissions has given rise to considerable debate especially with regard to the extent to which a person should be held liable for failing to rescue someone in peril. ${ }^{2}$ But the law has almost always imposed duties requiring action in status relationships involving power, trust or knowledge imbalances. For example, a duty arises where there is a close kinship relationship which requires the

1 Crimes Act 1961, s 2

2 For a detailed analysis of the debate on this issue see A Ashworth Positive Obligations in Criminal Law (Hart Publishing, Portland (Oregon), 2013) and in particular ch 2 "Criminalising Omissions". 
superior party to aid the weaker party to ensure the weaker party's survival. ${ }^{3}$ In New Zealand, as in many other jurisdictions, a parent is under a common law duty to protect her child. This duty extends to protecting the child from the violence of another. ${ }^{4}$

The enactment of s 195A followed a number of high profile child abuse cases. Most proximately connected, in the minds of the public at least, with failures in reporting was the case of three year old Nia Glassie who, in July 2007, was taken to hospital suffering severe injuries from which she died on 3 August. Her death came amid reports from neighbours that they had heard Nia screaming and crying, and that she had been seen spun from a clothesline until she fell off. ${ }^{5}$ Nia's mother, Lisa Kuka, was convicted of two counts of manslaughter on the basis of failing to provide the necessaries of life (medical treatment) and failing to protect Nia from violence. Kuka's partner, Wiremu Curtis, and his brother, Michael, were convicted of Nia's murder. Other adults in the house were convicted of various counts relating to the abuse of Nia and her siblings. In view of the fact that this case provided some impetus for the enactment of s 195A, it is somewhat paradoxical that none of the people (other than Kuka) who allegedly could have protected Nia by reporting the abuse would be liable under s 195A, as it only applies to people living in the same household, or a person who is a staff member of any hospital, institution, or residence where the victim resides. Kuka's liability arose by virtue of her position as Nia's mother, under the common law duty to protect one's children.

As Herring notes, statutes which penalise failure to protect are nearly always used against women and often in cases where there is a history of domestic violence. ${ }^{6}$ In Victoria, a recent proposal to enact a failure to protect law elicited much opposition on the basis of the adverse impact it would have on victims of domestic violence. ${ }^{7}$ The duty to protect presumes the defendant has the capacity to act positively to protect the victim, but this has implications for defendants who are also subjected to violence.

The enactment of s 195A has its imperative in a heightened awareness of the need for child protection, as shown in both the Parliamentary Debates and Select Committee report on the Bill. ${ }^{8}$ But in the understandable haste to prosecute and prevent child abuse, there is a risk of neglecting the

3 Theodore Y Blumoff "On the nature of the action-omission network" (2008) 24 Ga St U L Rev 1003 at 1009.

4 See $R v$ Lunt [2004] 1 NZLR 498 (CA) and s 151 of the Crimes Act 1961.

5 Catherine Masters "Nia Glassie case: behind the neighbours' silence" The New Zealand Herald (online ed, New Zealand, 19 November 2008)

6 Jonathan Herring "Familial homicide, failure to protect and domestic violence: who's the victim?" [2007] Crim L R 923 at 929.

7 See Michelle Griffin "Groups slam child protection law" The Age (online ed, Victoria, 9 September 2011).

8 See (3 May 2011) 672 NZPD 18316 and Crimes Amendment Bill (No 2) (284-2) (select committee report) at 1 . 
realities of other vulnerable people. To that end, the criminal justice system ought to reject a binary approach to victims and offenders. This entails recognition that often defendants may also be victims and that some mothers, due to the coercive control exerted by intimate partners, can also be "vulnerable adults". On this basis it is argued that rather than focussing on battered women it is preferable to direct attention to coerced women, since not all battered women are coerced and it is coercion, rather than violence per se, that may negate to some degree the voluntariness element of a failure to protect charge. However, each case needs to be considered in light of its own particular facts. Not every woman who fails to protect her child is coerced; not all coerced women will fail to protect their children.

\section{B The Psychological Effects of Abuse}

\section{The Battered Woman Syndrome}

For several decades there has been much research dedicated to understanding the psychological and other effects of domestic violence on victims. One of the earliest attempts at a comprehensive theory was that of psychologist Lenore Walker in her 1979 book The Battered Woman. In 1984 she published a follow-up book The Battered Woman Syndrome which detailed a study carried out with 400 battered women. There are two main elements in Walker's account of battered woman syndrome: the "cycle theory of violence" (cycle theory) and "learned helplessness". The cycle theory encompasses three phases: tension building; an acute battering incident; and loving contrition. ${ }^{9}$

In the tension building phase there is: $:^{10}$

... a gradual escalation of tension displayed by discrete acts causing increased friction such as namecalling, other mean intentional behaviours, and/or physical abuse. The batterer expresses dissatisfaction and hostility but not in an extreme or maximally explosive form. The woman attempts to placate the batterer, doing what she thinks might please him, calm him down, or at least, what will not further aggravate him.

However, the acute battering incident cannot be averted indefinitely, and this is then followed by the third phase of the cycle. The third phase consists of kind, loving and remorseful behaviour on the part of the abuser, which reinforces the cycle. ${ }^{11}$ He may even believe himself that he will never be violent again. ${ }^{12}$

9 Lenore Walker The Battered Woman Syndrome (Springer Publishing Company, New York, 1984) at 2.

10 At 95 .

11 At 2 .

12 At 96. 
The cycle theory purports to explain why women stay in abusive relationships. The loving contrition phase compensates for the acute abusive incidents. But Walker's study also showed that in many cases the third phase of the cycle could be characterised by an absence of tension and violence, with no observable loving-contrition, and still be reinforcing for the woman. ${ }^{13}$

Walker's theory of learned helplessness also explains why women find it difficult to leave abusive relationships. Relying on Seligman's (1975) experiments with dogs, Walker reasoned that helplessness arises when events in a woman's life seem uncontrollable. Seligman's experiments revealed that dogs who were repeatedly and randomly shocked became unable to escape the shocks even where escape was possible. ${ }^{14}$ Walker hypothesised that: ${ }^{15}$

... women's experiences of the noncontingent nature of their attempts to control the violence would, over

time, produce learned helplessness as the "repeated battering, like electrical shocks, diminish the

woman's motivation to respond".

It is important to note that Walker's theories do not describe all abusive relationships. Further, Walker's theories have been subjected to much criticism. Skinazi observes that neither Walker's own findings nor subsequent studies support a conclusion that learned helplessness is a common consequence of violent relationships. Notwithstanding this, many commentators agree that violent relationships do have psychological effects on survivors. ${ }^{16}$

\section{Traumatic bonding}

Dutton and Painter's theory of "traumatic bonding" posits that strong emotional attachments develop from two features of abusive relationships - power imbalances and intermittent good-bad treatment. ${ }^{17}$ As power imbalances increase in an abusive relationship, the subjugated party becomes less capable of fending for herself, and therefore perceives herself as increasingly in need of the dominator. ${ }^{18}$ Dutton and Painter also argue, drawing a link with Walker's contrition phase, that a series of positive behaviours on the part of the abuser offsets abusive episodes. The alternating aversive and positive conditions produce persistent patterns of behaviour that are difficult to extinguish, and in experiments produces strong emotional bonds. ${ }^{19}$ When physical punishment is

13 At 96 .

14 At 86.

15 At 87 .

16 Heather R Skinazi "Not just a 'conjured afterthought': using duress as a defense for battered women who 'fail to protect"' (1997) 85 CLR 993 at 1009.

17 Donald G Dutton and Susan Painter "Emotional attachments in abusive relationships: a test of traumatic bonding theory" (1993) 8 Violence and Victims 105 at 105.

18 At 107

19 At 107 
intermittent, and interspersed with friendly contact, traumatic bonding is most powerful. ${ }^{20}$ This emotional bond interferes with leaving, and staying out of, an abusive relationship. ${ }^{21}$

\section{Coercive controlling violence}

Michael P Johnson, with other researchers, has differentiated among types of domestic violence. ${ }^{22}$ Of particular relevance here is coercive controlling violence (previously referred to by Johnson and others as patriarchal terrorism and intimate terrorism), a term applied to "a pattern of emotionally abusive intimidation, coercion, and control coupled with physical violence against partners". ${ }^{23}$ This pattern is embodied in Pence and Paymar's Power and Control Wheel ${ }^{24}$ and many women's advocates, when using the term "domestic violence", refer to this pattern. ${ }^{25}$ The central idea of coercive control is that even nonviolent control tactics, such as isolation, economic abuse and so on, take on a violent meaning that they would not otherwise have. ${ }^{26}$ Coercive controlling violence can be distinguished from situational couple violence, a pattern of violence that is not grounded in the dynamic of power and control. Situational couple violence occurs when specific conflict situations escalate to violence. ${ }^{27}$ Distinguishing between these two patterns resolves the gender symmetry debate over whether women perpetrate violence against male partners as frequently as men do against women. Johnson's analysis shows that situational couple violence in heterosexual relationships is committed fairly equally by men and women, whereas coercive controlling violence is committed almost entirely by men. ${ }^{28}$

Furthermore, there are different consequences for the victim of each of these types of violence. Johnson and Leone report that women subjected to coercive controlling violence are more likely to: be injured; display more symptoms of posttraumatic stress syndrome; use painkillers, tranquilizers

20 At 108 .

21 At 109

22 See for example Joan B Kelly and Michael P Johnson "Differentiation among types of intimate partner violence: research update and implications for interventions" (2008) 46 Family Court Review 476; Michael P Johnson and Janel M Leone "The differential effects of intimate terrorism and situational couple violence: findings from the National Violence Against Women Survey" (2005) 26 Journal of Family Issues 322.

23 Kelly and Johnson, above n 22, at 478.

24 At 478.

25 At 478

26 Johnson and Leone, above n 22, at 323-324.

27 At 324.

28 At 325 
or antidepressants; miss work; leave their partners and do so more frequently. ${ }^{29}$ But despite this latter finding, such women are less likely to achieve and maintain self-sufficiency. ${ }^{30}$

\section{Coercive control}

Stark argues that while violence is critical in terms of the harm inflicted by abusive partners, most women with whom he has worked who only suffered violence retained autonomy in key areas of their lives. ${ }^{31}$ Stark's model of coercive control is not centred on violence as a tactic of control. He claims that the women he has seen in his practice have been adamant that: ${ }^{32}$

... what is done to them is less important than what their partners have prevented them from doing for themselves by appropriating their resources; undermining their social support; subverting their rights to privacy, self-respect, and autonomy; and depriving them of substantive equality.

Stark's "coercive control" model assumes that the battered mother is psychologically "normal" and possesses an average level of parental competence, but this competence is affected by the coercion she faces from the abuser. ${ }^{33}$ Thus the logic of a battered mother's actions can be located in the dynamics of coercive control. ${ }^{34}$ Stark suggests: ${ }^{35}$

... the only rational or ethical assumption on which protective services or justice can proceed, is that the child's safety and the mother's capacity to protect the child are compromised by the same source, the coercive strategies employed by the batterer. Thus, it is our failure to protect, not hers, that provides the proper basis for intervention.

Yet some commentators argue that a mother who fails to protect is no more a good parent than the person who inflicts the abuse. Liang and Macfarlane, for instance, suggest that a mother who intentionally places herself in an abusive relationship should not be characterised as a victim of that relationship. ${ }^{36}$ Arguments such as these can be readily dismissed on the basis that they

29 At 344

30 At 346.

31 Evan Stark Coercive control: how men entrap women in personal life (Oxford University Press, New York, 2007) at 13.

32 At 13 .

33 Evan Stark "A failure to protect: Unravelling 'the Battered Mother's Dilemma"' (1999-2000) 27 West St U L Rev 29 at 105

34 At 82.

35 At 110

36 Bryan A Liang and Wendy L Macfarlane "Murder by omission: child abuse and the passive parent" (1999) 36 Harv J on Legis 397 at 443. 
misunderstand the reality of coercive relationships and assume that women voluntarily place themselves within them.

\section{REASONABLE STEPS, OR BEYOND THE CALL OF DUTY?}

\section{A Gender Bias and "Reasonable Steps"}

Liability under s 195A of the Crimes Act 1961 is contingent upon a failure to take reasonable steps to protect a victim from risk of death, grievous bodily harm, or sexual assault. In respect of the common law duty, a mother may be liable if her omission constitutes a "major departure" from the standard of care expected of a reasonable person to whom the duty applies - that is, gross negligence must be proved. ${ }^{37}$ But, as Miccio observes, "in spite of neutral language, the reasonable parent or person is white, male, heterosexual and middle class". ${ }^{38}$ While the law applies equally to both mothers and fathers, defendants charged with failure to protect are almost always female, which cannot be explained solely by the fact that more women have custody of their children. ${ }^{39}$ Society expects that a mother will go further in order to protect her child - the mother is expected to take more than reasonable steps, to place the child's needs above her own. ${ }^{40}$ Accordingly, there is a gender bias in the system that holds women accountable for failing to protect their children, but many fathers are never held accountable for similar omissions or failing to be involved in their children's lives on any level. ${ }^{41}$ Jacobs compares the cases of Pauline Zile, the first woman in Florida to be convicted for first degree murder based on a failure to protect her daughter from her partner's violence, with that of David Schwarz, whose son was killed by his stepmother. No charges were laid against Schwarz, notwithstanding that he was living with the child and stepmother during the abuse. ${ }^{42}$ Jacobs also reports the case of Kimberly Novy, convicted of the murder of her stepson. She was prosecuted on the basis that if she had not inflicted the injuries herself, then she was accountable for failing to protect him from the boy's father, Keith Novy. Despite evidence that the child's abuse began at least nine months prior to Kimberly meeting Keith Novy, Keith was not

37 Crimes Act 1961, s 150A

38 G Kristian Miccio "A reasonable battered mother? Redefining, reconstructing, and recreating the battered mother in child protective proceedings" (1999) 22 Harv Women's L J 89 at 110.

39 Jeanne A Fugate "Who's failing whom? A critical look at failure-to-protect laws" (2001) 76 NYU L Rev 272 at 274

40 Michelle S Jacobs "Requiring battered women die: liability for mothers under failure to protect statutes" (1998) 88 J Crim L \& Criminology 579 at 587.

41 Leah E Daigle "Empowering women to protect: improving intervention with victims of domestic violence in cases of child abuse and neglect: a study of Travis County, Texas" (1998) 7 Texas Journal of Women and the Law 287 at $291-292$.

42 Jacobs, above n 40, at 582-584. 
prosecuted in relation to his son's death. ${ }^{43}$ There are numerous other cases where the same gender bias is apparent. ${ }^{44}$

\section{B Violence and "Reasonable Steps"}

The expectation that a mother must protect her children from harm is especially complicated in situations where she is also being victimised by an intimate partner. ${ }^{45}$ As Lindauer observes, "[b]eing a good mother is difficult. Being a good mother and a victim of domestic violence is even harder." ${ }^{46}$ The link between spousal abuse and child abuse is well established, ${ }^{47}$ and Stark argues that domestic violence against a mother may be the single most common context for child abuse or neglect. ${ }^{48}$ However, domestic violence advocates claim that women are held unfairly responsible for failing to protect their children from a battering partner's abuse. ${ }^{49}$ Rather than establishing male perpetrators of domestic violence as accountable for the resulting child abuse, some evidence suggests that it has increased the visibility and accountability of abused women as mothers who failed to protect their children. ${ }^{50}$ Consequently, a battered woman who kills her abuser is better able to defend herself than a battered woman charged with failing to protect her child. ${ }^{51}$ Furthermore, some jurisdictions prosecute battered women for exposing their children to intimate partner violence. ${ }^{52}$

In his article, "A Failure to Protect: Unravelling 'The Battered Mother's Dilemma"', Evan Stark tells the story of Lavonne Lazarra, a mother of five, charged with abuse and neglect of her children. Stark had been asked to assess whether domestic violence perpetrated against Lazarra by her

43 At 613-614.

44 See for example Fugate, above n 39.

45 Miriam J Landsman and Carolyn C Hartley "Attributing responsibility for child maltreatment when domestic violence is present" (2007) 31 Child Abuse and Neglect 445 at 446.

46 Margo Lindauer "Damned if you do, damned if you don't: why multi-court-involved battered mothers just can't win" (2012) 20 Am U J Gender Soc Pol'y \& L 797 at 797.

47 Skinazi, above n 16, at 995.

48 Evan Stark "The battered mother in the child protective service caseload: developing an appropriate response" (2002) 23 Women's Rts L Rep 107 at 109.

49 Landsman and Hartley, above n 45, at 446.

50 Einat Peled "Abused women who abuse their children: a critical review of the literature" (2011) 16 Aggression and violent behaviour 325 at 328 .

51 Skinazi, above n 16, at 993.

52 Lindauer, above n 46, at 798. 
partner, Miguel Sabastian, was a factor in her offending. Stark sets out in detail the history of the relationship between Lazarra and Sabastian, which began early in 1991. By September 1992: ${ }^{53}$

Lavonne was increasingly unable to function as an autonomous adult, neglecting basic household

chores, losing state assistance and living for a time without basic comforts. The focus of her life shifted

to sheer survival: living like a virtual hostage, every element of Lavonne's life was oriented toward

placating or resisting Miguel, minimizing the hurt he could do to her and the children.

Sabastian would wake Lavonne up whenever he pleased, either by initiating sex or by suffocating her so she would wake gasping for air. When she did wake, Sabastian would feign sleep. Other times he would slap her while she was sleeping. Eventually Lavonne would pretend to be asleep, which led to chronic fatigue. ${ }^{54}$

Of Lavonne's five children, Sabastian was the biological father of the youngest, Miguelito. Sabastian clearly favoured Miguelito but singled out Lavonne's second youngest child, Candy, as a target for his anger. ${ }^{55}$ Candy was fathered by Sabastian's cousin, a man of whom Sabastian was particularly jealous as Lavonne's most recent partner before him. Lavonne began putting Candy in the cellar when Miguel wanted Candy "out of his sight". ${ }^{56}$ Knowing that Candy was a particular target for Sabastian's violence, and feeling that Candy was "too young to be hit", 57 it is not unreasonable to view Lavonne's conduct as an attempt to protect Candy. This is not a view that prosecutors took, however, charging Lavonne with neglect for leaving Candy in the cellar unattended.

Jonathan Herring chronicles the case of Sandra Mujuru who was convicted under s 5 of the Domestic Violence, Crime and Victims Act 2004 (UK) for failing to protect her daughter, Ayesha, from the violence inflicted by her partner, Jerry Stephens (Ayesha's father). Stephens was convicted of murder. Mujuru was found to have known of Stephens' propensity for violence since she knew he had been imprisoned for violence against a previous girlfriend. By leaving Ayesha in Stephens' care while she went to work, Mujuru was found to have failed to reasonably protect Ayesha. ${ }^{58}$

53 Stark, above n 33 , at 70.

54 At $72-73$.

55 At 73.

56 At 75 .

57 At 73 .

58 Herring, above $\mathrm{n} 6$, at 926 . 
But, as Herring points out, the Court gave little weight to Mujuru's circumstances as an asylum seeker fleeing violence in Zimbabwe. The sentencing Judge noted that Stephens was twice the age of Mujuru and characterised him as a dangerous man with a short fuse. Herring asks: ${ }^{59}$

As a young asylum-seeker should she really have been expected to know from which authorities to seek

advice and how to access the appropriate services? Could she have done this without endangering her

child and herself by igniting her partner's 'dangerously short fuse'?

Also of relevance to these questions is the fact that on the day Ayesha's body was found, Stephens had assaulted one of his previous girlfriends by hitting her on the head with a frying pan and a vase. ${ }^{60}$

Regardless of the precise theory explaining a coerced woman's behaviour, it is clear that there are complex dynamics that may compel her to remain with her abuser. ${ }^{61}$ Further, it is understandable why it may have been unreasonable for such a woman to interfere with a batterer's abuse of a child. Based on her experience, she may have reasonably feared that interference would either increase the abuse to the child or precipitate deadly violence against herself and the child. ${ }^{62}$ Yet such fears, even though reasonable, are often ignored in legal decision-making. Herring refers to a case in which a woman was criticised by the Judge as "putting her interests first" where the partner said he would kill her if she left. ${ }^{63}$ Fugate refers to the case of Karen Dalton, whose husband had conducted a regime of violence against her and her children, including putting a gun to her children's heads and threatening to kill her son if she tried to leave the relationship. Dalton was also aware that her husband had murdered at least two women. Yet the court took a dim view of her claims of coercion, demonstrated through its repeated use of quotation marks around what it referred to as her "defense of fear". 64

\section{Subjective "Reasonable Steps"?}

In what is arguably a rare decision, in Bone v HM Advocate, ${ }^{65}$ the High Court of Justiciary, Scotland, did take into account detailed evidence bearing on the question of the reasonableness of the appellant's inaction. Andrea Bone was charged with manslaughter by witnessing and countenancing her partner's abuse of her daughter. Bone was convicted and appealed, arguing that

59 At 926 .

60 At 926 .

61 Skinazi, above n 16, at 1004.

62 At 1006.

63 Herring, above $\mathrm{n} 6$, at 927.

64 Fugate, above n 39, at 291; see In Re Dalton 424 NE 2d 1226 (Ill App 1981).

65 Bone v Her Majesty's Advocate [2005] HCJAC 154, 2006 SLT 164. 
parental responsibility does not involve criminal responsibility where the appellant is powerless to intervene; and that in assessing the reasonableness of the alleged failure to protect, regard must be had to the particular circumstances of the appellant. In that case, there was evidence about the size and strength disparities between Bone and Alexander McClure (her partner), she was eight and a half months pregnant, was affected by personality disorders (including dependent personality disorder) and possessed a low level of intellectual functioning. There was also evidence that she had not intervened at the time of the assaults because she believed it was not appropriate to argue in the presence of her daughter, but she had spoken to her partner afterwards about his violence. She was scared of McClure, and was isolated socially and geographically. The High Court of Justiciary agreed with counsel for the appellant that the relevant test was not a wholly objective one: ${ }^{66}$

In the context of the question whether a parent witnessing an assault on a child could reasonably have acted to protect the child, it is not appropriate to test the matter by reference to a hypothetical reasonable

parent; rather the test is whether the particular parent, with all her personal characteristics and in the situation in which she found herself, could reasonably have intervened to prevent the assault.

What is particularly interesting about this case, in the current context, is that while it was noted that Bone was scared of McClure, nothing in the judgment indicates he inflicted physical violence upon her, as opposed to her child. This lends support to Stark's theory that physical violence, by itself, may play a less significant role than coercion, in terms of impact on victims and their ability to protect their children.

\section{HELPLESS VICTIMS OR ACTIVE PERPETRATORS?}

But should coerced women be seen as helpless victims or as active perpetrators of offences against their children? As Chiu asks, "[a]re they purely agents, purely victims, or a combination of both?" ${ }^{67}$ Chiu continues: ${ }^{68}$

If battered women are victims, then they do not contribute to the violence and should not be penalized in any way; as victims, they are too debilitated to make their own choices. On the other hand, if battered women are active agents, then policies should examine, and perhaps, even punish their choices.

Ultimately it might be found that coerced women are victims, but not completely helpless ones. ${ }^{69}$ This conclusion finds support in actual cases, such as that of New Zealand mother, Tania Witika. Witika's daughter, Delcelia, died alone while Witika and her boyfriend, Eddie Smith, were at a party. Delcelia had suffered massive blows to her stomach, which ruptured her intestine causing

66 Bone v HM Advocate, above n 65, at [9].

67 Elaine Chiu "Confronting the agency in battered mothers" (2001) 74 S Cal L Rev 1223 at 1239.

68 At 1240 .

69 At 1255. 
peritonitis. She also had her teeth knocked out, burns to her limbs and buttocks, bruises and sores covering her body. ${ }^{70}$ The pathologist was of the opinion that Delcelia had also been subjected to prolonged and chronic sexual abuse. ${ }^{71}$ Both Witika and Smith were found guilty of manslaughter and sentenced to 16 years imprisonment. They were both also found guilty of failing to provide Delcelia with the necessaries of life, being medical care. The case was described by Gault $\mathbf{J}$ as, "a case of wicked child abuse"72 in which Delcelia was, "subjected to violence and brutality of almost incomprehensible cruelty and was neglected appallingly". ${ }^{73}$

The Crown was unable to prove which of the accused actually committed the acts of violence against Delcelia, but charged them both, either as principal offenders or as parties through encouragement. On appeal against sentence, the Court of Appeal observed that both Witika and Smith committed acts of violence against Delcelia and were "equally culpable". ${ }^{74}$

Witika also appealed against her conviction, arguing that the common law defence of duress applied to the charges of failing to provide medical treatment and her secondary participation in Smith's abuse of Delcelia. The Court of Appeal dismissed the appeal, on the basis that a claim of duress must be founded on s 24 of the Crimes Act 1961, which required that the threatener be present during the offending, and there were periods of time during which Smith was absent from the house. According to Gault J: ${ }^{75}$

$\ldots$ it is quite clear that there were substantial periods during which Smith was not present and Witika had opportunities to seek assistance and secure medical care for her child and otherwise bring an end to her ill-treatment. While those periods continued she failed in her duty. Her situation was no different from that of a person who has an opportunity to escape and avoid committing acts under threat of death or serious injury.

He continued: ${ }^{76}$

The position of battered women indeed calls for sympathy but there can be no justification for broadening the grounds on which the law should provide excuses for child abuse.

What should be made of Tania Witika? A few more facts are enlightening. In her first interview with police on the day Delcelia died, Witika exonerated Smith from any responsibility. Two days

70 D McLoughlin "The Canonisation of Tania Witika" North \& South (New Zealand, December 1998) at 32.

$71 R v$ Witika [1993] 2 NZLR 424 (CA) at 430.

72 At 427 .

73 At 429 .

74 At 440.

75 At 436 .

76 At 436. 
later she recanted and blamed Smith for all of the injuries. In a third interview after the post-mortem results were made available she acknowledged some responsibility for failing to put a stop to Smith's abuse of Delcelia. She also admitted to some punching of Delcelia. But Witika's prevarication is consistent with evidence that Smith had violently beaten her on a number of occasions. A doctor who examined Witika in September 1990 described her injuries as being close to 10 on a severity scale from $0-10$. Further evidence of Witika's mutability comes from her own diary, in which she wrote: ${ }^{77}$

"I hit Delc really bad yesterday and it gave me a real fright and that's when I knew I had to stop hitting her. Not for my sake but for hers."

"I'm really happy with myself, cause I am learning to control my anger and that's good, cause I'm not hitting Delc out of anger and I don't want to any more either only for a good reason."

These entries, on one hand, show at least a consciousness of the riskiness of her conduct. But they also reveal a woman who tried to be a good mother to Delcelia. Thus Witika, vilified in mainstream news media, is not simply a perpetrator of child abuse but also someone who made some attempts to alter her behaviour and protect her child. The status of mothers like Witika, and the many others charged with failures in respect of their children, is not dichotomous: they are not bad mothers or good mothers, perpetrators or victims, agents or helpless. They can be all of these things, both at different times and at the same time.

Even battered women may not see themselves as victims. The law usually perceives victimisation as a unilateral exercise of power, in which harm is caused to a "weak" victim. Part of the problem with using the term "victim" as a descriptor is that it downplays an individual's strengths and capacities. ${ }^{78}$ Agency, on the other hand, implies total freedom from victimisation, which is not always accurate either. Neither of these two concepts - agency or victimisation completely takes account of women's experiences of coercive relationships. ${ }^{79}$ As Schneider notes: ${ }^{80}$

Portrayal of women as solely victims or agents is neither accurate nor adequate to explain the complex realities of women's lives. It is crucial for feminists and feminist legal theorists to understand and explore the role of both victimization and agency in women's lives, and to translate these understandings into the theory and practice that we develop.

77 At 436

78 Jacobs, above $\mathrm{n} 40$, at 602 .

79 At 602 .

80 Elizabeth M Schneider "Describing and changing: women's self-defense work and the problem of expert testimony on battering" (1992) 14 Women's Rts L Rep 213 at 239. 
For many years the legal picture of the battered woman has been dominated by the creature of learned helplessness - a victim who, due to repeated cycles of violence, is unable to escape ${ }^{81}$ But contrary to this legal view, studies suggest that battered women make multiple attempts to leave. ${ }^{82}$ Rigid depictions of battered women prevent the recognition of significant reactions to abuse, other than failing to protect. For example, some women act as a buffer between an abuser and the child; others reduce their working hours so they can spend more time at home. ${ }^{83}$ Brown tells of one woman who used her sexuality to distract her partner from harming her son. Despite her efforts, he would interrupt sexual intercourse to continue to abuse the child. Her attempts at distraction were also not accepted by the Court as actions taken to save the boy's life. ${ }^{84}$

For some women, failure to protect may actually represent a survival strategy rather than a failure. Some women know only too well that interfering with an intimate partner during a violent episode may have engendered only more violence toward herself and her children. ${ }^{85}$ Skinazi argues: ${ }^{86}$

Partner assault involves coercion and control over every aspect of a person's life. Structural inequalities, the systemic nature of women's oppression, and the harms associated with domination and resistance reinforce this power. Child abuse represents an extension of the batterer's coercive tactics from mother to child. Hence, if a mother believes that her chances to escape with her children are limited, given the backdrop of the assailant's previous conduct (i.e., hunting the family down and threatening to kill them if the mother does not return to him), her escape options may be restricted. In such a situation, the word

"choice" certainly takes on a new meaning.

A coerced mother knows what her abuser is capable of when he threatens to harm her or the children if she disobeys or leaves. This explains why a mother may try to placate her abuser at almost any cost to save her children from harm, perhaps even staying with the partner or "allowing" the abuse, if she thinks it will prevent greater harm to her children. ${ }^{87}$ Intervening or shielding a child from a violent and angry person is often not only dangerous, but lethal to the intervener and the child. $^{88}$

81 Jacobs, above n 40, at 604 .

82 Miccio, above n 38, at 103.

83 Jacobs, above n 40, at 604-605.

84 Geneva Brown "When the bough breaks: traumatic paralysis - an affirmative defense for battered mothers" (2005) 32 Wm Mitchell L Rev 189 at 239.

85 Skinazi, above n 16, at 1028

86 At 1030 .

87 At 995-996.

88 At 996. 
It is important at this point to reiterate that not all mothers who are charged with failures to their children are battered women. A mother may believe that she and her child are better off financially by staying with an abusive partner, or she may have other reasons for staying. Lisa Kuka, referred to in the introduction to this article, was convicted of failing to provide the necessaries of life (medical treatment) and failure to protect her daughter, Nia, from violence. Kuka, who worked away from the home six days a week, admitted that she knew of but "turned a blind eye" to the violence in her home because her loyalties were to her partner, Wiremu Curtis, who was convicted (along with his brother) of Nia's murder. ${ }^{89}$ There was no evidence raised at trial to suggest that Kuka was subjected to physical violence from Curtis or anyone else. As Stark suggests, however, violence is not the only tactic of control. Kuka did give evidence that when she argued with others in the house over their treatment of Nia, their excuses were "we look after her[,] you're at work, where are you[?]"90 It is conceivable, therefore, that Kuka's economic situation and the recriminations levelled at her for her absence provided a context for her alleged failure to protect.

A final premise that ought to be accepted is that agency is not the same thing as control, and even playing an active role does not always connote blameworthiness. ${ }^{91}$ Agency does not mean that coerced women have the ability to control their abuse. It is not justifiable to penalise coerced women every time they do not use their agency to end the abuse. The lives of abused women are complex, and not every action or choice such a woman makes is to avoid or affect future violence. ${ }^{92}$

\section{$V$ DEFENDING COERCED WOMEN CHARGED WITH FAILURE TO PROTECT}

Despite the clear link between spousal abuse and child abuse and neglect, no consistent theory has yet been developed for the defence of mothers that is based on the connection between the abuse they receive and their ability to prevent harm to their children. ${ }^{93}$ While public awareness of child abuse did increase at the same time as domestic violence awareness, the sad paradox is that what also increases is the likelihood of a mother being prosecuted for failure to protect. ${ }^{94}$

Everyone charged with a criminal offence has the right to defend herself. The current legal position in New Zealand exposes a coerced mother to prosecution for failure to protect, for which she is liable if her failure is seen as unreasonable, or as a major departure from a reasonable standard of care. There are no statutory or common law defences that operate to exculpate her. Compulsion

$89 R v$ Kuka [2009] NZCA 572 at [63].

90 At [63].

91 Chiu, above n 67, at 1257-1258.

92 At 1258.

93 Jacobs, above n 40, at 585.

94 At 585. 
and necessity involve stringent tests and will rarely, if ever, apply in this context. Self-defence is clearly irrelevant, provocation has been repealed, and New Zealand does not have a defence of diminished responsibility.

In New Zealand, battered woman syndrome has previously played a role in some self-defence and provocation cases. The legal position of the syndrome was summarised in $R v$ Oakes ${ }^{95}$ Gay Oakes killed her long-time partner, Doug Gardner, by giving him an overdose of sleeping pills. In her defence it was argued that Oakes suffered from battered woman's syndrome, brought about by years of physical and verbal violence perpetrated against her by Gardner. The expert called for the defence said that the significant aspect of the syndrome was its effect on a woman's sense of judgement, her vulnerability and the ability to reason rationally. ${ }^{96}$ The Court accepted the existence of "the syndrome" and its effects, ${ }^{97}$ and noted that evidence that an accused suffered from battered woman's syndrome makes it more plausible that she could have been mistaken about how dangerous her situation was. Since the question of whether the force used in self-defence is reasonable depends upon the circumstances as the accused believed them to be, a pre-emptive strike might be justified. ${ }^{98}$ However, the Court also observed: ${ }^{99}$

It hardly needs to be said that a battered woman has no more right to kill or injure than any other person, man or woman. And so that fact that a woman suffers from the syndrome is not in itself a defence; the syndrome is not in itself a justification for the commission of a crime.

\section{A Compulsion and Necessity}

In New Zealand, there are two potential avenues for defending a coerced mother charged with failure to protect - compulsion and necessity. The essential argument here is that a mother who is in a relationship characterised by coercive control is unable to protect her child because her will has, to some degree, been overborne - in other words, she is under duress. It is critical to note that from a factual perspective, duress is not an either/or proposition - it exists in degrees. However, as the following discussion will show, these defences as currently applied do not work satisfactorily in the context of failure to protect.

The defence of compulsion is provided for by s 24 of the Crimes Act 1961:

$95 R$ v Oakes [1995] 2 NZLR 672 (CA).

96 At 676 .

97 At 675 .

98 At 676 .

99 At 675 
[A] person who commits an offence under compulsion by threats of immediate death or grievous bodily harm from a person who is present when the offence is committed is protected from criminal responsibility if he believes that the threats will be carried out ...

As noted earlier, in $R v$ Witika, the defence of compulsion was held not to apply unless there is evidence of a continuing threat of immediate death or grievous bodily harm, made by a person who is present and in a position to carry out the threat. The Court of Appeal has also said that if there is a chance of escape, the claim that the accused acted under compulsion might be questioned. Whether there is a continuing threat of the kind required by s 24 when there is an opportunity to seek help is a question of fact. ${ }^{100}$ This is relevant to the belief of the accused at the material time. The test in relation to the accused's belief is a subjective one, but: ${ }^{101}$

... nevertheless a question of fact does arise whether such belief is genuinely held which the prosecution must negate beyond reasonable doubt. Whether such a belief was reasonable or well grounded would be relevant to the issue whether it was genuinely held.

The second option, necessity, is not a statutory defence and falls within a grey area in New Zealand law. It has been linked to the defence of duress of circumstances and, as Simester and Brookbanks note, the status of these two concepts as separate defences has been in doubt. ${ }^{102}$ In Police v Kawiti the phrase "defence of necessity of circumstances" was used. ${ }^{103}$ In $R v$ Hutchinson "duress of circumstances" was used to denote necessity. ${ }^{104}$

To the extent that necessity exists at common law, it is preserved by s 20 of the Crimes Act 1961. The essence of the defence is that the defendant was faced with a choice between the lesser of two evils, whereby the lesser evil involved a criminal offence.

In $R v$ Hutchinson Heath $\mathrm{J}$ examined the background of the defence of necessity. The defendant, Hutchinson, was charged with burglary and wilful destruction of a quantity of 1080 poison, to be used by the Department of Conservation for possum control. Hutchinson was a member of an action group which opposed the use of 1080 poison on the basis of potential harm to humans and other animals. ${ }^{105}$

$100 R$ v Raroa [1987] 2 NZLR 486 (CA).

101 At 492

102 Andrew Simester and Warren Brookbanks Principles of Criminal Law (3rd ed, Brookers, Wellington, 2007) at 392 .

103 Police v Kawiti [2000] 1 NZLR 117 (HC).

$104 R v$ Hutchinson [2004] NZAR 303 (CA).

105 Above $n 104$ 
Justice Heath noted that aspects of the broad defence of necessity have been codified in New Zealand for example, self-defence and defence of another and compulsion. Because there had not been full argument on a number of important questions, Heath $\mathrm{J}$ thought the way to proceed was to "assume, without deciding, that the defence of duress of circumstances exists", ${ }^{106}$ the elements of which were those that were stated in an earlier case, Kapi v Ministry of Transport. ${ }^{107}$ In Kapi, a driver charged with failing to stop after an accident claimed necessity on the basis that he feared for his life due to the alleged violent nature of the locale. The Court of Appeal held that even if there is a common law defence of necessity, it would not be available in situations of the kind that arose in that case, as the defence of compulsion covers all cases where the criminal act is done under threat of harm or grievous bodily harm from a person who is present when the offence is committed. ${ }^{108}$ The Court continued: ${ }^{109}$

We do not consider s 20 can be said to preserve a common law defence of duress by threat or fear of death or grievous bodily harm from a person not present.

The judgment in Kapi would therefore seem to be fatal to the operation of the defence of necessity for women coerced by their intimate partners. Nevertheless, the Court also held that the elements of necessity in New Zealand are: ${ }^{110}$

(a) a belief on reasonable grounds of imminent peril of death or serious injury;

(b) circumstances in which the accused has no realistic choice but to break the law; and

(c) a breach of the law proportionate to the peril involved.

In $R v$ Hutchinson Heath $\mathrm{J}$ concluded that there must also be a nexus between the imminent peril and the choice to respond by unlawful means. ${ }^{111}$ However, on the facts of that case, the defence did not apply since the defendant's will was not so overborne by the threat that he had no realistic choice.

The difficulties encountered in arguing either of these defences in the context of failure to protect charges is summarised in the following paragraphs. For the defence of compulsion to succeed it must be proved that a coerced mother was in fact faced with threats of immediate death or grievous bodily harm, from a person who is present when the offence is committed. The threat does not have to be explicit. She must also believe that the threats will be carried out. In a relationship

$106 R v$ Hutchinson, above $\mathrm{n} 104$, at 313.

107 Kapi v Ministry of Transport (1991) 8 CRNZ 49 (CA).

108 At 55 .

109 At 55

110 At 57

$111 R v$ Hutchinson, above n 104, at 311. 
characterised by coercive controlling violence, while a court could find threats of immediate death or grievous bodily harm, the defence is likely to fail on the requirement that the threatener be present when the offence is committed, as was the case in $R v$ Witika. This is particularly the case in failure to protect cases because of the ongoing nature of the offence. It is also difficult to prove the subjective belief of the coerced mother - the fact that she remains with her abuser is likely to be construed by a jury as evidence that she did not take the threats seriously.

Necessity has similar difficulties, even if it were to apply to threats from another person, contrary to the ruling in Kapi v Ministry of Transport. Again, a court may find that the mother did believe that she faced imminent peril of death or serious injury (whether this is on reasonable grounds may be less easy). They are also less likely to find that she had no realistic choice but to break the law, or that the failure to protect was proportionate to the peril. As mentioned previously, a mother is expected to to place her child's needs above her own ${ }^{112}$ and is at risk of being criticised for putting herself first for trying to avert a threat against her own life. ${ }^{113}$

Essentially, both compulsion and necessity presume that the defendant has options that are not necessarily available to the coerced mother, and ignore her ability to accurately perceive a real risk. As Skinazi observes: ${ }^{114}$

Consideration of the defendant's heightened ability to predict her partner's behavior toward herself and her children - a skill she has developed through a history of abuse with her partner - is crucial in determining whether the defendant's responses to his threats were, in fact, reasonable. Additionally, because in most of these cases, the paradigm "gun to the head," or some other obviously extreme example of duress, is not present, or at least not apparent, a jury using an objective standard of reasonableness is not likely to believe that the defendant acted reasonably under a sufficiently imminent threat.

In addition, traumatic bonding may mean that a victim of abuse becomes emotionally dependent on the abuser and is convinced that the violence has stopped or is about to. ${ }^{115}$ Thus, while the death of child might seem foreseeable to others, that is not necessarily so for women within the abusive relationship. ${ }^{116}$ Brown argues that Dutton and Painter's theory of traumatic bonding could be used as a psychological foundation for an affirmative defence of "traumatic paralysis", the essence of

112 Jacobs, above n 40, at 587.

113 Herring, above $\mathrm{n}$ 6, at 927 .

114 Skinazi, above n 16, at 1003.

115 Herring, above n 6, at 929.

116 At 929. 
which is that the emotional bond a mother has with her abuser means she is incapable of protecting herself or her children. ${ }^{117}$

\section{B A New Standard - Totality of Circumstances}

Skinazi argues that, in most United States jurisdictions, the asymmetrical treatment of the reasonable person standard in duress as compared with self-defence leads to very different results. ${ }^{118}$ Accordingly, she proposes a new duress standard as follows: ${ }^{119}$

The defense of duress is determined by considering whether, under the totality of the circumstances (including past abuse), the threat (implicit or explicit), or the use of force, was such that the actor believed she could not resist, and a reasonable person similarly situated could not resist.

Skinazi's proposed duress standard stresses a responsible actor who possesses self-direction and exercises agency. It also distinguishes between mothers who hurt their children, and mothers who hurt their children in an effort to protect them. ${ }^{120}$ Expert evidence is essential to explain to a jury that an abused or coerced woman develops survival skills, and in light of these skills, it may be reasonable to obey the abuser's instructions. ${ }^{121}$ The totality of a woman's circumstances, available resources and the past pattern of her partner's abusive behaviour, may mean she makes a fully controlled decision, based on reasonable inferences and involving intentional behaviour. ${ }^{122}$ This latter point is important, as characterising her choices as involuntary may imply that she is psychologically impaired and unable to take care of her children. ${ }^{123}$

Because the defence ought to exculpate only women whose will is to some degree overborne by another, explicit reference to coercion ought to be made. Also, the use of the term "resist" in Skinazi's proposal unnecessarily limits the operation of the defence. While the duress defence usually counters crimes of commission, ${ }^{124}$ what is crucial about coercion in respect of failure to protect is that it prevents the mother from acting as much as resisting.

In New Zealand self-defence is composed of a similar hybrid test which asks whether, in the circumstances as the accused believed them to be, the force used in self-defence (or defence of

117 Brown, above n 84, at 239

118 Skinazi, above n 16, at 993.

119 At 1024.

120 At 1035.

121 At 1010.

122 At 1010.

123 At 1010-1011.

124 Brown, above n 84, at 235. 
another) was reasonable. Also, although envisaging different circumstances, the recently repealed provocation defence constructed a hypothetical person, possessing the self-control of the "ordinary" person, yet otherwise having the characteristics of the accused. Potentially, these hybrid tests allow for a consideration of the totality of the circumstances faced by a coerced mother. Indeed, this was the test held to apply in Bone $v$ HM Advocate. It allows a jury to consider the totality of the circumstances - "all her personal characteristics and ... the situation in which she found herself" 125 - in determining whether a mother's alleged failure was a reasonable one.

In New Zealand, the offence of failing to protect a child from the violence of another takes on an almost strict or absolute liability nature due to the elements that must be proved and the absence of a defence. All that must be proved is the omission and that it was a major departure from the standard of care expected of a reasonable mother. Neither the defendant's actual conduct, nor her state of mind (apart from knowledge of the abuse) ${ }^{126}$ factors into the analysis at all. As Ashworth observes, most of the controversy over strict liability offences stems from the absence of a fault requirement for conviction. For the same reason, he notes that there is much debate over the extent to which criminalising negligence is legitimate. ${ }^{127}$ Many commentators take the view that, as Horder puts it, it should not be possible to "blunder into" conduct that is seen as morally wrong. ${ }^{128}$ The criminal law should only convict those who are culpable in some way and we should only label someone a "criminal" if they are blameworthy. Accordingly, if a person is not to blame for some harm, the reproach of the criminal law is not appropriate. ${ }^{129}$

Another argument against the criminalisation of negligence in the context of failures by parents to protect their children is that where there are duties owed by doctors, employers, drivers and so on, there are also settled rules or codes of conduct which delimit the standards that such defendants are expected to observe. This is not the case in respect of parents, for whom there are few, if any, formal rules and a diverse range of practice. ${ }^{130}$ Consequently, it is difficult for parents to know the standards they are expected to meet and could therefore be found grossly negligent, and liable for manslaughter if the child dies, through very little fault on their part. ${ }^{131}$

125 Bone v HM Advocate, above n 65, at 167.

$126 R v K u k a$, above n 89, at [58].

127 Andrew Ashworth "Conceptions of overcriminalization" (2008) 5 Ohio State Journal of Criminal Law 407 at 411 .

128 Jeremy Horder "Gross negligence and criminal culpability" (1997) 47 UTLJ 495 at 495.

129 Simester and Brookbanks, above n 102, at 8 .

130 Horder, above n 128, at 518-519.

131 At 519 . 
For similar reasons, an affirmative defence is preferable in the context of failure to protect charges than relying on evidence that negates mens rea. This is because evidence of the mother's state of mind is irrelevant, once it is established that she owed a duty of care. While the court must prove knowledge of the abuse this knowledge is bound up with the question of whether the defendant failed to perform a legal duty and whether such failure was a major departure from the standard of care expected of a reasonable person or parent having such a legal duty. In other words, it is not relevant to subjective mens rea. Furthermore, courts have traditionally been reluctant to allow expert evidence on whether or not an accused was acting with intent, as this would be a matter on which the jury must ultimately decide, ${ }^{132}$ although s 25(2) of the Evidence Act 2006 states that expert evidence is not inadmissible simply for the fact that it breaches the "ultimate issue" rule.

Notwithstanding that there are valid arguments against the enactment of failure to protect statutes, such laws already exist and no doubt will continue to come into existence. It is therefore suggested that, where such charges arise, from either common law or statutory duties, an affirmative defence ought to be available. This defence could take a similar form to that proposed by Skinazi, with some modification as follows:

\footnotetext{
A person charged with failure to protect a child or vulnerable adult from the violence of another is protected from criminal responsibility if she was acting under coercion. Coercion is determined by considering whether, under the totality of the circumstances (including past abuse), the threat (implicit or explicit), or the use of force, was such that the actor was coerced to the extent she was unable to resist or to take positive action and a reasonable person similarly situated could not resist or take positive action.
}

There is clearly a gap in the law in New Zealand, and possibly other jurisdictions, that could be filled by such an affirmative defence. It could potentially also be expanded to apply to coerced women facing any charge, not just failure to protect.

\section{CONCLUSION}

In many cases, convicting a coerced mother for failure to protect will not benefit children, but re-victimises both mother and child who have both suffered enough abuse. ${ }^{133}$ It is difficult to see what functions of the criminal law are served by criminalising coerced mothers who fail to protect their children. As Fugate argues, courts wrongly assume that the threat of imprisonment will encourage mothers to protect their children when they otherwise would not. ${ }^{134}$ Even in cases where a child dies as a result of the abuse inflicted by another, little is achieved by convicting a coerced mother for manslaughter. Often, there are other children who will invariably be placed in care,

$132 R$ v Makoare [2001] 1 NZLR $318(\mathrm{CA})$ at 323.

133 Skinazi, above n 16, at 999.

134 Fugate, above n 39 , at 290 
exposing them to a greater risk of abuse and neglect. Studies show that there is a low chance of families being reunified after removal, and there are substantial risks to children in foster care. ${ }^{135}$ Consequently, Murphy argues that courts should have a complete understanding of the mother's circumstances and if she has participated in the abuse or neglect of her children, courts should identify the contributing factors, particularly with a view to the possibility of domestic violence. ${ }^{136}$ Arguably the preventative function of the criminal law is better served by focusing on those who actually inflict violence against children. Ultimately, a mother who has participated in the abuse or neglect of her children should be accountable for the resulting harm, but only to the extent to which her participation was truly voluntary.

135 Jane C Murphy "Legal images of motherhood: conflicting definitions from welfare 'reform', family and criminal law" (1998) 83 Cornell L Rev 688 at 712.

136 At 712 . 